\title{
Non-steroidal anti-inflammatory drugs and the risk of cardiovascular diseases
}

\author{
Are we going to see the revival of cyclooxygenase-2 selective inhibitors?
}

\author{
Piotr Głuszko, Aneta Bielińska \\ Department of Rheumatology and Balneology, Jagiellonian University, Medical College, Kraków, Poland
}

\section{KEY WORDS}

adverse events, coxibs, non-steroidal anti-inflammatory drugs, recommendations, risk of cardiovascular events
Correspondence to:

Assoc. prof. Piotr Głuszko,

MD, PhD, Zakład Reumatologii i Balneologii, Uniwersytet Jagielloński, Collegium Medicum, ul. Śniadeckich 10, Kraków, Poland, phone: + 48-12-424-88-78, fax: +48-12625-47-55, e-mail: zruj@mp.pl

Received: July 23, 2008. Revision accepted: October 16, 2008

Conflict of interest: none declared. Pol Arch Med Wewn. 2009; 119 (4): 231-235 Translated by Agnieszka Narkun Copyright by Medycyna Praktyczna, Kraków 2009

\begin{abstract}
The use of non-steroidal anti-inflammatory drugs (NSAID) is associated with a number of gastrointestinal and other adverse effects. Introduction of selective cyclooxygenase-2 (COX-2) inhibitors at the end of the 20th century raised hopes for a substantial reduction in the rate of serious events such as upper gastrointestinal ulcers, bleeding and perforations. In 2004 and 2005, predictions of some pharmacologists were confirmed when the Adenomatous Polyp Prevention on VIOXX trial (APPROVE) and other randomized, double-blind, placebo-controlled trials with COX-2 inhibitors showed an increased rate of thrombotic vascular events, including myocardial infarction, in patients treated with coxibs. So far, only limited long-term data on cardiovascular risk associated with non-selective NSAID have been available; however, some studies have suggested that both selective COX-2 inhibitors and traditional NSAID increase the risk of cardiovascular events. For patients at high cardiovascular risk, contradictory warnings and recommendations have been published recently by the American Heart Association, Food and Drug Administration, and by independent experts. The current paper reviews these recommendations and discusses the therapeutic challenge to minimize the risk of serious adverse events associated with the use of NSAID.
\end{abstract}

Historical note Salicylic acid, used for centuries in the treatment of inflammation, both as a natural component of plant extracts and in a purified form, has been poorly tolerated by patients because of its unpleasant taste and adverse effects. Since synthesis of acetylsalicylic acid (ASA) and the introduction of aspirin in 1899, non-steroidal anti-inflammatory drugs (NSAID) have continued to be commonly used worldwide. It is barely conceivable today that back in the 1920s and 1930s, patients would take even up to several grams of ASA daily. Later, when it became clear that ASA caused a range of harmful adverse effects, mainly ulcers, perforations and upper gastrointestinal bleedings, ${ }^{1}$ the search for a safer alternative began. Nevertheless, the representatives of newer NSAID generation - phenylbutazone and indomethacin, available since 1949 and 1945 , respectively; ${ }^{2}$ and later ketoprofen, diclofenac and naproxen - showed similar adverse effects despite many differences in their pharmacokinetic properties (TABLE 1). Although John Vane's explanation of ASA's mechanism of action in $1971^{3}$ was a Nobel Prize level discovery, it did not contribute to do research for safer NSAID. The major breakthrough came with the discovery of 2 arachidonic acid cyclooxygenase (COX) izoenzymes in 1990: constitutional cyclooxygenase-1 (COX-1) and inducible cyclooxygenase-2 (COX-2) synthesizing pro-inflammatory prostaglandins. ${ }^{4}$ A new concept was immediately developed to selectively block only the COX-2 enzyme responsible for the production of pro-inflammatory mediators. Most of the previously used traditional NSAID and ASA inhibited both izoenzymes to a lesser or greater extent, exerting the anti-inflammatory effect but also decreasing the synthesis of "physiological" eicosanoides. Non-selective COX inhibitor-induced ulcers (including ibuprofen, naproxen, ketoprofen, indomethacin, 
TABLE 1 Typical adverse effects of cyclooxygenase-1 and cyclooxygenase-2 inhibitors on multiple organs and systems

\begin{tabular}{|c|c|}
\hline gastrointestinal tract & $\begin{array}{l}\text { dyspepsia, nausea, vomiting, gastritis complicated } \\
\text { with bleeding, peptic ulcers }\end{array}$ \\
\hline hematopoiesis & $\begin{array}{l}\text { thrombocytopenia, } \\
\text { hypoprothrombinemia } \\
\text { anemia, granulocytopenia }\end{array}$ \\
\hline kidneys & $\begin{array}{l}\text { acute kidney failure } \\
\text { hematuria, proteinuria } \\
\text { interstitial nephritis } \\
\text { nephrotic syndrome } \\
\text { renal papillary necrosis }\end{array}$ \\
\hline liver injury & increased aminotransferase activity \\
\hline $\begin{array}{l}\text { skin and systemic } \\
\text { allergic reactions }\end{array}$ & $\begin{array}{l}\text { aspirin-induced asthma } \\
\text { skin allergy, erythema, edema, drug-induced } \\
\text { eruptions, urticaria } \\
\text { very rarely Stevens-Johnson syndrome }\end{array}$ \\
\hline sense organs & $\begin{array}{l}\text { hearing disturbances and vision disorders, vertigo and } \\
\text { auditory noises }\end{array}$ \\
\hline
\end{tabular}

diclofenac) are explained by COX-1 inhibition in the gastric mucosa. ${ }^{4-6}$

In the 1990s, pharmaceutical companies competed with one another to be the first on the market with a selective or perhaps preferable COX-2 inhibitor. ${ }^{4}$ This class of drugs came to be commonly known as coxibs. Numerous multicenter, randomized clinical trials with rofecoxib, celecoxib, valdecoxib and etoricoxib were conducted and demonstrated anti-inflammatory and analgesic effects of these agents together with a lower rate of upper gastrointestinal adverse effects compared to conventional NSAID. ${ }^{7-10}$ At the beginning of the 21st century, a view about high effectiveness and a substantially better safety profile of coxibs prevailed, ${ }^{10}$ strengthened by effective marketing. Nonetheless, ever since a potential selective COX-2 inhibition was discovered, a number of pharmacologists emphasized the fact that inhibition of prostacyclin synthesis by coxibs, with unrestricted production of prothrombotic thromboxane in platelets, could potentially upset the balance and increase the risk of thrombotic complications. ${ }^{11,12}$ Selective COX-2 inhibitors were not free of adverse effects, similar to those of traditional NSAID, including water and sodium resorption, which could lead to edema, hypertension, heart failure, dyspnea, vertigo, abdominal pain, dyspepsia, diarrhea, and gastric or duodenal ulcers etc.

COX-2 inhibitors and cardiovascular complications A warning signal came from the VIOXX Gastrointestinal Outcomes Research trial with rofecoxib (VIGOR) ${ }^{8}$ which showed comparable effectiveness of naproxen and rofecoxib in a symptomatic treatment of rheumatoid arthritis (RA) and a smaller number of serious upper gastrointestinal side effects in the rofecoxib group.

To investigators' surprise, $0.4 \%$ of RA patients taking rofecoxib (Vioxx) experienced myocardial infarction as compared to $0.1 \%$ of patients in the naproxen group. This observation was at that time accounted for by the inhibitory effect of naproxen (similar to ASA) on platelet aggregation, although other causes were postulated.

While the adverse effects of both medication groups on the cardiovascular system are coincident in the majority of cases; their reliability level has the strength of "experts' recommendations". An increased risk of thrombotic events, myocardial infarction, and stroke should be strongly emphasized.

The almost simultaneously conducted Celecoxib Long-Term Arthritis Safety Study (CLASS), assessing the effect of celecoxib and diclofenac, did not show an increased risk of cardiovascular events in any of the groups. ${ }^{7}$ However, an urgent need for further verification of cardiovascular risk in patients treated with selective COX-2 inhibitors (celecoxib, etoricoxib, rofecoxib, valdecoxib) was recognized, and the prophylactic use of low-dose ASA while administering coxibs to patients with thrombotic risk factors was suggested by expert panels. ${ }^{10}$

Controversies and discussions over the issue persisted for the next 4 years, until the Merck company finally decided to withdraw rofecoxib (Vioxx) from the market in September 2004, ${ }^{13}$ following the observation from the Adenomatous Polyp Prevention on VIOXX trial (APPROVE), ${ }^{14}$ in which 31 subjects (2.4\%) out of 1287 participants taking rofecoxib (Vioxx) developed cardiac complications (myocardial infarction, sudden cardiac death, unstable angina). Similar incidents occurred in 12 patients $(0.9 \%)$ in the control group of 1299 subjects receiving placebo. It was observed that a statistically significant increase in cardiovascular events occurred after 18 months of regular rofecoxib administration. More cerebrovascular events ( $1.2 \%$ vs. $0.5 \%$ in the control group) were reported in the rofecoxib group.

These findings prompted government agencies, pharmaceutical companies and expert groups to meticulously examine all currently available and newly introduced selective COX-2 inhibitors with relation to a risk for cardiovascular complications. Placebo-controlled trials showed that a slightly increased risk of thrombotic vascular incidents, including myocardial infarction, was associated with the entire class of drugs, ${ }^{9,15}$ although the risk level varied depending on an individual drug. However, meta-analyses of these trials demonstrated that the prevalence of cardiovascular events in the compared "patient-years" is similar and the risk of myocardial infarction is almost twice higher in patients treated with coxibs (relative risk [RR] 1.86, 95\% CI: 1.33-2.59, $\mathrm{p}=0.0003)$.

The already discussed analysis of the studies by Patricia Kearney's group revealed that $2 / 3$ of all vascular events occurred in clinical trials with follow-up of a year or more; however, there are no data available on the risk associated with a dose of medication. 
TABLE 2 Step-up strategy of analgesic therapy

\begin{tabular}{l}
\hline paracetamol, ASA, tramadol, narcotics (short acting) \\
\hline non-acetylated salicylates (rarely used in Poland) \\
\hline non-selective NSAID \\
\hline preferiential COX-2 inhibitors \\
\hline selective COX-2 inhibitors
\end{tabular}

Abbreviations: ASA - acetylsalicylic acid, COX-2 - cyclooxygenase-2,

NSAID - non-steroidal anti-inflammatory drugs

NSAID and the heart: current views and recommendations An increased risk of myocardial infarction associated with administration of coxibs directed scientists' attention to the need for reducing adverse cardiovascular effects of all non-selective NSAID (e.g. diclofenac, ketoprofen, indomethacin, naproxen, piroxicam) because they inhibit both COX-1 and COX-2, although to a varying extent. These drugs inhibit platelet thromboxane synthesis to a substantially smaller extent and within short-term periods, because only ASA does it irreversibly, ${ }^{16}$ and that is where the cause of thrombotic complications is sought. Additionally, NSAID often cause hypertension. ${ }^{19}$

In the MEDAL (Multinational Etoricoxib versus Diclofenac Arthritis Long-term) study ${ }^{17}$ of 34,701 patients with osteoarthritis or RA treated for about 18 months, the prevalence of thrombotic cardiovascular events was compared. There were no statistically significant differences in the outcomes between patients treated with etoricoxib and diclofenac. In the CLASS trial ${ }^{7}$ and in various other trials comparing the risk of cardiovascular events associated with the use of selective COX-2 inhibitors and traditional NSAID (except naproxen) no significant differences were observed. ${ }^{9}$ Interestingly, in some clinical trials on non-selective NSAID vs. placebo, a higher rate of vascular events was found in groups treated with ibuprofen (RR 1.51, 95\% CI: 0.96-2.37) and diclofenac (RR 1.63, 95\% CI: 1.12-2.37). Naproxen differed from other NSAID, being an exception because apparently it did not increase cardiovascular risk (RR 0.92, 95\% CI: 0.67-1.26).8,9

All the data and findings have been recognized by the Food and Drug Administration (FDA), the American Heart Association (AHA), the European Medicines Agency (http://www.emea.europa.eu), together with organizations and relevant offices in many countries. ${ }^{18}$ In the case of traditional NSAID (and coxibs, e.g. celecoxib currently available on the market), the FDA (http://www.fda.gov) recommended that warnings should be placed on medication packages (black box). The warnings should read as follows: "NSAID can increase the risk of serious thrombotic cardiovascular events, a heart attack, a stroke, which may cause death. This risk can increase with the duration of therapy. People suffering from cardiovascular diseases or with risk factors may be more vulnerable." Much the same warning concerns celecoxib, in the case of which an additional sentence was placed saying that all NSAID might also increase the risk. Similar warnings have also appeared in Poland. ${ }^{19}$

In 2007, the $\mathrm{AHA}^{18}$ published recommendations regarding the use of NSAID which underline the need for individual assessment of benefits and potential damage associated with each drug. In patients with a known cardiovascular risk, who require administration of symptomatic drugs because of rheumatic indications, it has been proposed to intensify the therapy starting with medications with the lowest risk of cardiovascular complications (TABLE 2).

If the first 2 therapeutic options are not effective or are poorly tolerated by the patient and it is necessary to continue their use, after including the increased potential risk, NSAID are administered according to the following rules:

1 the lowest effective dose should be prescribed and the treatment duration reduced to minimum

2 patients with an increased risk should receive ASA in a dose of $81 \mathrm{mg} / \mathrm{d}$ (in Poland a $75 \mathrm{mg}$ dose is available) simultaneously with a proton pump inhibitor

3 blood pressure and renal function should be regularly monitored; the patient should be monitored to detect potential edema

4 if side effects occur a drug should be changed or a dose reduced.

The safety of NSAID use is of great significance in rheumatology because these drugs have to be taken for several years by many patients. It is now known that RA patients suffer from heart infarct and other vascular complications twice as often as healthy people. On the other hand, most patients with arthrosis are elderly, which involves various risk factors such as overweight, dyslipidemia, diabetes, hypertension, and increased vulnerability to gastrointestinal complications. It is well known that effectiveness and individual reactions to NSAID are highly variable. When choosing a drug the patient's preferences must be considered. Regardless of pharmacological controversies around interactions between ASA and NSAID on the enzyme level, ${ }^{20}$ administration of low doses of ASA with a non-selective or selective COX-2 inhibitor is most probably associated with an increased risk of gastrointestinal toxicity. Either taking ASA together with a coxib, or using a coxib with a proton pump inhibitor makes treatment with the selective COX-2 inhibitor questionable and must raise controversy. ${ }^{21}$

Attempts to balance between naproxen (which seems to be safe for the heart as the selective COX-1 inhibitor in platelets, but its usage is associated with an increased risk of ulcers, perforations, inflammation and bleeding in the gastrointestinal tract), diclofenac (which inhibits COX-1 only in $30 \%$ and probably increases the risk of myocardial infarction) and finally further clinical trials are needed to demonstrate the value of selective COX-2 inhibitors. ${ }^{20}$ During the EULAR conference held in Paris in June 2008, an outstanding 
Italian pharmacologist Carlo Patrono underlined ${ }^{22}$ the fact that there were two contradictory approaches to therapeutic management:

1 the AHA recommendations suggesting that the use of selective COX-2 inhibitors should be limited to individual cases ${ }^{18}$

2 preferred administration of COX-2 inhibitors with low-dose ASA. ${ }^{23}$

There is consensus about the need for conducting further trials, lowering the doses and shortening therapy to the minimum, informing patients about potential benefits and risks, eliminating the use of non-prescription NSAID and treating the modifiable cardiovascular risk factors such as dietary habits, cigarette smoking, hypertension, overweight and hypercholesterolemia.

Concerns regarding further therapeutic strategy have been well described by a pharmacologist from Philadelphia, Garret A. FitzGerald, ${ }^{20}$ who indicates adverse FDA regulations resulting in the practical absence of etoricoxib on the market. With regard to other NSAID a special warning about the risk of cardiovascular complications (black box) placed on the package is recommended. FitzGerald has expressed the view that based on the same premises, celecoxib, diclofenac and perhaps meloxicam could be withdrawn from the market, because, e.g., the same risk of thrombotic events is associated with both diclofenac and etoricoxib. On the other hand, in comparison with other NSAID, celecoxib and other coxibs do not reduce gastrointestinal side effects to such extent as it has previously been thought. ${ }^{21}$ While commenting on the AHA guidelines, FitzGerald ${ }^{20}$ quoted the trials indicating that the average $1 \mathrm{~g}$ dose of paracetamol daily inhibits both COX-1 and COX-2 in 50\%, whereas a dose over $2 \mathrm{~g}$ daily may induce gastrointestinal complications. It is not known either whether all NSAID can be used similarly. In some patients (could we identify them?) naproxen will probably display cardioprotective effects (unfortunately it causes gastrointestinal injury), whereas diclofenac and meloxicam should not be administered to patients with cardiovascular diseases. There have been no data necessary to assess whether in such patient groups naproxen is safer than ibuprofen and selective COX-2 inhibitors are indeed the last choice.

COX-2 inhibitors do not interfere with the cardioprotective effect of low-dose ASA, ${ }^{20}$ nevertheless it is not known to what extent ASA and perhaps the treatment of secondary hypertension decrease the risk of cardiovascular complications during such therapy and how this approach influences the overall safety profile of the therapy.

The concept to use coxibs together with ASA and gastroprotective medication questions the introduction of selective COX-2 inhibitors to the market as agents with a better safety profile, nevertheless it might appear to be the safest and most effective therapeutic option.

\section{REFERENCES}

1 Day RO, Furst $\mathrm{DE}$, Graham GG, Champion GD. The clinical pharmacology of aspirin and the salicylates. In: Paulus HE, Furst DE, Dromgoole SH eds. Drugs for rheumatic disease. Churchill Livingstone New York 1987 227-263

2 Furst DE, Dromgoole SH. Indomethacin and Sulindac. In: Paulus $\mathrm{HE}$, Furst DE, Dromgoole SH, eds. Drugs for rheumatic disease. Churchill Livingstone New York 1987: 285-231.

3 Vane JR. Inhibition of prostaglandin synthesis as a mechanism of action for aspirin-like drugs. Nature. 1971; 231: 232-235.

4 Vane JR. Towards a better aspirin. Nature. 1994; 367: 215-216.

5 Cryer B, Feldman M. Cyclooxygenase-1 and cyclooxygenase-2 selectivity of widely used nonsteroidal anti-infammatory drugs. Am J Med. 1998; 104: 413-421.

6 Simon LS. Are the biologic and clinical effects of the COX-2 specific in hibitors an advance compared with the effects of traditional NSAIDs? Curr Opin Rheumatol. 2000; 12: 163-170.

7 Silverstein FE, Faich G, Goldstein JL, et al. Gastrointestinal toxicity with celecoxib vs nonsteroidal anti-inflammatory drugs for osteoarthritis and rheumatoid arthritis: the CLASS study: A randomized, controlled trial. JAMA. 2000; 284: 1247-1255

8 Bombardier C, Laine L, Reicin A, et al. Comparison of upper gastrointestinal toxicity of rofecoxib and naproxen in patients with rheumatoid arthritis. VIGOR Study Group. N Engl J Med. 2000; 343: 1520-1528.

9 Kearney PM, Baigent C, Godwin J, et al. Do selective cyclo-oxygenase 2 inhibitors and traditional non-steroidal anti-inflammatory drugs increase the risk of atherothrombosis? Meta-analysis of randomised trials. BMJ. 2006; 332: 1302-1308

10 Lipsky PE, Abramson SB, Breedveld FC, et al. Analysis of the effect of COX-2 specific inhibitors and recommendations for their use in clinical practice. J Rheumatol. 2000; 27: 1338-1340.

11 McAdam BF, Catella-Lawson F, Mardini IA et al. Systemic biosynthesis of prostacyclin by cyclooxygenase (COX)-2: the human pharmacology of a selective inhibitor of COX-2. Proc Natl Acad Sci USA. 1999; 96: 272-277.

12 Topol EJ, Failing the public health: rofecoxib, Merck, and the FDA N Engl J Med. 2004; 351: 1707-1709.

13 Głuszko P. [Short history of Vioxx]. Medycyna Praktyczna. 2004; 10 186-188. Polish.

14 Baron JA, Bresalier RS, Sandler R et al. Cardiovascular events associated with rofecoxib in a colorectal adenoma chemoprevention trial. N Engl J Med. 2005; 352: 1092-1102.

15 Grosser T, Fries S, FitzGerald GA. Biological basis for the cardiovascular consequences of COX-2 inhibition: therapeutic challenges and opportunities. J Clin Invest. 2006; 116: 4-15.

16 Patrono C. Aspirin as an antiplatelet drug. N Engl J Med. 1994; 330 : 1287-1294.

17 Cannon CP, Curtis SP, FitzGerald GA, et al. Cardiovascular outcomes with etoricoxib and diclofenac in patients with osteoarthritis and rheumatoid arthritis in the Multinational Etoricoxib and Diclofenac Arthritis Long-term (MEDAL) programme: a randomised comparison. Lancet. 2006; 368: 1771-1781.

18 Antman EM, Bennett JS, Daugherty A, et al. Use of nonsteroidal antiinflammatory drugs. AHA Scientific Statements. Circulation. 2007; 115: 1634-1642.

19 [Practical Medicine Drug Index 2007]. Medycyna Praktyczna. 2007. Kraków 2007: 137, 360. Polish

20 FitzGerald GA. COX-2 in play at the AHA and the FDA. Trends Pharmacol Sci. 2007; 28: 303-307.

21 Garcia Rodriguez LA, Barreales Tolosa L. Risk of upper gastrointestina complications among users of traditional NSAIDs and COXIBs in the general population. Gastroenterology. 2007; 132: 498-506.

22 Patrono C. Use of NSAIDs in patients at high risk for cardiovascular complications. Ann Rheum Dis. 2008; 67 (Suppl 2): 8.

23 Strand V. Are COX-2 inhibitors preferable to non-selective non-steroidal anti-inflammatory drugs in patients with risk of cardiovascular events taking low-dose aspirin? Lancet. 2007; 370: 2138-2151. 


\title{
Niesteroidowe leki przeciwzapalne a ryzyko chorób serca i naczyń
}

\section{Czy czeka nas renesans koksybów?}

\author{
Piotr Głuszko, Aneta Bielińska \\ Zakład Reumatologii i Balneologii, Uniwersytet Jagielloński, Collegium Medicum, Kraków
}

\section{SŁOWA KLUCZOWE}

działania niepożądane, koksyby, niesteroidowe leki przeciwzapalne, ryzyko wystąpienia incydentów sercowo-naczyniowych, zalecenia

\begin{abstract}
STRESZCZENIE
Stosowanie niesteroidowych leków przeciwzapalnych (NSLPZ) jest związane z ryzykiem wystąpienia powikłań ze strony przewodu pokarmowego i innych efektów ubocznych. Wprowadzenie pod koniec $\mathrm{XX}$ wieku do terapii selektywnych inhibitorów cyklooksygenazy 2 (COX-2) dało nadzieję na znaczącą redukcję poważnych działań niepożądanych ze strony górnego odcinka przewodu pokarmowego, tj. owrzodzeń, krwawień i perforacji. W 2004 i 2005 roku, zgodnie z przewidywaniami części farmakologów, badanie APPROVE i inne badania kliniczne z randomizacją, prowadzone metodą podwójnie ślepej próby z użyciem placebo nad selektywnymi inhibitorami COX-2 wykazały zwiększenie częstości występowania incydentów zakrzepowych, w tym zawału serca, u pacjentów leczonych koksybami. Dysponujemy ograniczoną liczbą danych dotyczących ryzyka wystąpienia powikłań sercowo-naczyniowych związanych ze stosowaniem nieselektywnych NSLPZ. Część doniesień wskazuje jednak na to, że zarówno selektywne inhibitory COX-2, jak i tradycyjne NSLPZ zwiększają to ryzyko. Ostatnio w odniesieniu do pacjentów z grupy dużego ryzyka wystąpienia incydentów sercowo-naczyniowych publikowane są sprzeczne ostrzeżenia i zalecenia Amerykańskiego Towarzystwa Kardiologicznego, Urzędu ds. Żywności i Leków USA oraz niezależnych ekspertów. W naszym opracowaniu przeanalizowaliśmy dostępne zalecenia i wyzwania terapeutyczne, których gtównym celem jest zminimalizowanie ryzyka wystąpienia poważnych działań ubocznych związanych ze stosowaniem NSLPZ.
\end{abstract}

